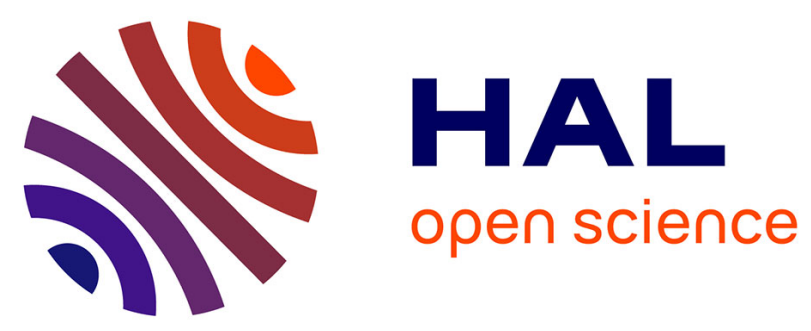

\title{
Oceanic Dispersion Simulations of 137Cs Released from the Fukushima Daiichi Nuclear Power Plant
}

Yukio Masumoto, Yasumasa Miyazawa, Daisuke Tsumune, Takaki Tsubono, Takuya Kobayashi, Hideyuki Kawamura, Claude Estournel, Patrick Marsaleix, Lyon Lanerolle, Avichal Mehra, et al.

\section{To cite this version:}

Yukio Masumoto, Yasumasa Miyazawa, Daisuke Tsumune, Takaki Tsubono, Takuya Kobayashi, et al.. Oceanic Dispersion Simulations of 137Cs Released from the Fukushima Daiichi Nuclear Power Plant. Elements, 2012, 8 (3), pp.207-212. 10.2113/gselements.8.3.207 . hal-02110121

\section{HAL Id: hal-02110121 https://hal.science/hal-02110121}

Submitted on 10 Aug 2021

HAL is a multi-disciplinary open access archive for the deposit and dissemination of scientific research documents, whether they are published or not. The documents may come from teaching and research institutions in France or abroad, or from public or private research centers.
L'archive ouverte pluridisciplinaire HAL, est destinée au dépôt et à la diffusion de documents scientifiques de niveau recherche, publiés ou non, émanant des établissements d'enseignement et de recherche français ou étrangers, des laboratoires publics ou privés. 


\section{Oceanic Dispersion Simulations of ${ }^{137} \mathrm{Cs}$ Released from the Fukushima Daiichi Nuclear Power Plant}

Yukio Masumoto ${ }^{1}$, Yasumasa Miyazawa ${ }^{1}$, Daisuke Tsumune ${ }^{2}$, Takaki Tsubono ${ }^{2}$, Takuya Kobayashi ${ }^{3}$, Hideyuki Kawamura ${ }^{3}$, Claude Estournel $^{4}$, Patrick Marsaleix ${ }^{4}$, Lyon Lanerolle ${ }^{5,6}$, Avichal Mehra ${ }^{7}$, and Zulema D. Garraffo ${ }^{8}$

Five models have been used to estimate the oceanic dispersion of 137Cs from the Fukushima Daiichi nuclear power plant during March and April 2011, following the accident on March 11, 2011. The total actividtiys cohf a1r3g7Ceds is estimated to be 2 to 15 petabequerels. A weak southward current along the Fukushima coast was responsible for the initial transport direction, while mesoscale eddy-like structures and surface-current systems contributed to dispersion in areas beyond the continental shelf. Most of the discrepancies among the models in April are caused by differences in how the mesoscale current structures off the Ibaraki coast are represented.

KeYwords: oceanic dispersion simulation, radionuclides, ${ }^{137} \mathrm{Cs}$, Fukushima Daiichi nuclear power plant, regional ocean simulation, mesoscale eddy

\section{INTRODUCTION}

A devastating earthquake and huge tsunami struck the Tohoku area, Japan, on March 11, 2011, causing major damage to the cooling systems of reactors in the Fukushima Daiichi nuclear power plant, operated by Tokyo Electric Power Company (TEPCO). In order to cool the reactor cores and the spent fuel in storage pools, large amounts of seawater and freshwater were used. A significant part of this radioactivity-contaminated water was discharged into the Pacific Ocean close to the power plant. In addition, several hydrogen explosions between March 12 and 15 resulted in the release of significant radioactivity into the atmosphere, some of which was deposited onto the sea surface over a wide area of the Pacific Ocean. Careful monitoring combined with modeling of the dispersion of the radioactivity provide critical information (1) on the processes responsible for dispersion of the radionuclides, (2) for simulation and prediction of the spread of radioactivity in the seawater, and (3) for the evaluation of the impact on the health of marine ecosystems and humans.

Since the accident at the Fukushima plant, several groups have been conducting numerical dispersion simulations of radionuclides discharged into the ocean, each group having different objectives. Some of the results from the simulations have been used to determine locations of monitoring observations off the east coast of Japan. This article reviews the present status of such simulations, without considering atmospheric deposition, and describes common aspects and discrepancies among the simulated results. The article also points out potential problems and provides guidance for future studies. This is the first attempt to conduct an intercomparison of models for the oceanic dispersion of ${ }^{137} \mathrm{Cs}$ from the Fukushima plant.

\section{DISPERSION SIMULATION} MODELS

Numerical simulations of the dispersion of radionuclides in the ocean basically consist of two parts: an ocean circulation model and a radionuclide dispersion model. The ocean circulation model provides evolving circulation patterns for the dispersion model, while the dispersion model calculates the movement and spread of radionuclides in the ocean. In this article, we compare results from five groups: the Central Research Institute of Electric Power Industry (CRIEPI), the Japan Atomic Energy Agency (JAEA), the Japan Coastal Ocean Predictability Experiment (JCOPE) group at the Japan Agency for Marine-Earth Science and Technology (JAMSTEC), the Simulation Réaliste de l'Océan Côtier (Sirocco) group from the Observatoire Midi-Pyrénées, Centre National de la Recherche Scientifique and Toulouse University, and the National Oceanographic and Atmospheric Administration (NOAA) group.

Each group utilized a different set of models (TABLE 1). All of the models have their finest regional domain resolution focused on the area close to the nuclear plant, with various grid spacings in both the horizontal and vertical directions. Lateral boundary conditions of the circulation models are typically obtained from larger domain ocean circulation models, with relatively coarse resolutions, into which observed data, such as temperature, salinity, and sea-surface height, are assimilated to provide realistic upper-ocean conditions. With these assimilation schemes, mesoscale eddies and meandering of ocean currents, which are crucial
1 Research Institute for Global Change Japan Agency for Marine-Earth Science and Technology

Yokohama, Kanagawa 236-0001, Japan

2 Environmental Science Research Laboratory, Central Research Institute of Electric Power Industry, 1646 Abiko Abiko-shi, Chiba-ken 270-1194, Japan

3 Japan Atomic Energy Agency, 2-4 Shirane Shirakata, Tokai-mura, Naka-gun Ibaraki 319-1195, Japan
4 CNRS, Toulouse University, Laboratoire d'Aérologie, 14 Avenue Edouard Belin F-31400 Toulouse, France

5 Earth Resources Technology, Inc. Laurel, Maryland 20707, USA

6 National Oceanic and Atmospheric Administration Silver Spring, Maryland 20910, USA
7 National Centers for Environmental Prediction/National Weather Service/ National Oceanic and Atmospheric Administration

Camp Springs, Maryland 20746, USA

8 I.M. Systems Group, Inc. Camp Springs, Maryland 20746, USA

Corresponding author: Yukio Masumoto (masumoto@jamstec.go.jp) 


\begin{tabular}{|c|c|c|c|c|c|c|c|c|c|}
\hline \multirow[b]{2}{*}{$\begin{array}{l}\text { Model } \\
\text { name }\end{array}$} & \multicolumn{2}{|c|}{ Base model } & \multirow[b]{2}{*}{ Resolution $^{\mathrm{a}}$} & \multirow[b]{2}{*}{$\begin{array}{c}\text { Nesting } \\
\text { (parent model) }\end{array}$} & \multirow[b]{2}{*}{ Winds } & \multirow[b]{2}{*}{$\begin{array}{c}\text { Data } \\
\text { assimilation }\end{array}$} & \multirow[b]{2}{*}{ Tides } & \multirow[b]{2}{*}{$\begin{array}{l}\text { Integration } \\
\text { period }\end{array}$} & \multirow[b]{2}{*}{ Reference } \\
\hline & Circulation & Dispersion & & & & & & & \\
\hline EA & $\begin{array}{l}\text { Kyoto U./ } \\
\text { JMSF }^{\text {b }}\end{array}$ & SEA-GEARN ${ }^{\mathrm{c}}$ & $1 / 72^{\circ} \times 1 / 54^{\circ}$ & $\begin{array}{l}\text { 2-step, }\left(1 / 24^{\circ} \times 1 / 18^{\circ} \text { near }\right. \\
\text { Japan, } 1 / 8^{\circ} \times 1 / 6^{\circ} \text { North } \\
\text { Pacific, Kyoto U./JMSFb })\end{array}$ & $\begin{array}{l}\text { NCEP reanalysis } 2^{\mathrm{d}} \\
\text { and JMA- MSM }\end{array}$ & 4D-VAR & No & $\begin{array}{l}\text { March 11- } \\
\text { April } 30\end{array}$ & $\begin{array}{l}\text { Kawamura et al. } \\
\text { (2011) }\end{array}$ \\
\hline RIEPI & ROMS $^{\mathrm{f}}$ & Passive tracer & $1 \mathrm{~km}$ & 1-step, $\left(1 / 12^{\circ}\right.$ HYCOM $\left.^{g}\right)$ & NuWFAS & $\begin{array}{l}\text { Included in } \\
\text { HYCOM }\end{array}$ & Yes & $\begin{array}{l}\text { March 1- } \\
\text { May } 31\end{array}$ & $\begin{array}{l}\text { Tsumune et al. } \\
\text { (2011) }\end{array}$ \\
\hline COPET & $\mathrm{JCOPE}^{\mathrm{i}}$ & Passive tracer & $1 / 36^{\circ}$ & $\begin{array}{l}\text { 2-step, }\left(1 / 12^{\circ} \text { Northwest }\right. \\
\text { Pacific, } 1 / 4^{\circ} \text { North Pacific, } \\
\left.\text { JCOPE }^{\mathrm{i}}\right)\end{array}$ & $\begin{array}{l}\text { NCEP analysis and } \\
\text { JMA-MSM }\end{array}$ & $\begin{array}{l}\text { 3D-VAR in } \\
\text { JCOPE2 }\end{array}$ & Yes & $\begin{array}{l}\text { March 21- } \\
\text { May } 6\end{array}$ & \\
\hline írocco & Sirocco $^{\mathrm{i}}$ & Passive tracer & $600 \mathrm{~m}$ & 1-step, $\left(\mathrm{NCOM}^{\mathrm{k}}\right)$ & ECMWF forecast $^{1}$ & $\begin{array}{l}\text { Included in } \\
\text { NCOM }\end{array}$ & Yes & $\begin{array}{l}\text { March 11- } \\
\text { to present }\end{array}$ & $\begin{array}{l}\text { Toulouse } \\
\text { University (2011) }\end{array}$ \\
\hline NOAA & $\mathrm{ROMS}^{\mathrm{f}}$ & Passive tracer & $1 \mathrm{~km}$ & 1-step, $\left(\mathrm{NCOM}^{\mathrm{k})}\right)$ & $\begin{array}{l}\text { US Navy's } \\
\text { COAMPS } \\
\text { (via NCOM) }\end{array}$ & $\begin{array}{l}\text { Included in } \\
\text { NCOM }\end{array}$ & Yes & $\begin{array}{l}\text { March 10- } \\
\text { June } 27\end{array}$ & \\
\hline & $\begin{array}{l}\text { a The finest } g \\
\text { et al. 2009). } \\
\text { Modeling Sy } \\
\text { Forecasting } \\
\text { sirocco.omp. } \\
\text { Model (Barro } \\
\text { Atmosphere }\end{array}$ & $\begin{array}{l}\text { rid spacing is ir } \\
\text { c Kobayashi et } \\
\text { tem (Shchepet } \\
\text { nd Analysis Sys } \\
\text { bs-mip.fr/outi } \\
\text { n et al. 2004). } \\
\text { Mesoscale Pred }\end{array}$ & $\begin{array}{l}\text { dicated, if grid } \\
(2007) .{ }^{d} \text { Kan } \\
\text { in and McWillic } \\
\text { em (Hashimoto } \\
\text { /Symphonie/Pr } \\
\text { European Cent } \\
\text { tion System (h }\end{array}$ & $\begin{array}{l}\text { system is variable in space. } \\
\text { lamitsu et al. (2002). e Japan } \\
\text { lams 2005). }{ }^{9} \text { Hybrid Coordin } \\
\text { o et al. 2010). 'Japan Coastal } \\
\text { roduits/Japan/SymphoniePre } \\
\text { tre for Medium-Range Weath } \\
\text { tttp://www.nrlmry.navy.mil/ }\end{array}$ & $\begin{array}{l}\text { Kyoto University and } \\
\text { Meteorological Agen } \\
\text { ate Ocean Model (ht } \\
\text { Ocean Prediction Exp } \\
\text { ijapanDescript.htm/. } \\
\text { er Forecasts (http://h }\end{array}$ & $\begin{array}{l}\text { apan Marine Sc } \\
- \text { Meso-Scale I } \\
\text { ://hycom.org/) } \\
\text { riment (Miyaza } \\
\text { The U.S. Navy } \\
\text { /w.ecmwf.int/). }\end{array}$ & $\begin{array}{l}\text { cience Fo } \\
\text { Model. } \\
\text { h Nume } \\
\text { awa et al } \\
\text { Operatic } \\
\text { m Coup }\end{array}$ & $\begin{array}{l}\text { undation (Ishikas } \\
\text { Regional Ocean } \\
\text { rical Weather } \\
\text { 2009). j http:// } \\
\text { nal Global Ocea } \\
\text { ed Ocean/ }\end{array}$ & \\
\hline
\end{tabular}

for the radionuclide dispersion in the open ocean, are adequately represented. Tidal currents are also included in several models in order to reproduce realistic spatialtemporal current variations near the coastal regions.

Although most of the groups are conducting dispersion calculations for several radionuclides, such as ${ }^{131} \mathrm{I},{ }^{134} \mathrm{Cs}$, and ${ }^{137} \mathrm{Cs}$, we focus only on ${ }^{137} \mathrm{Cs}$ in this article, since it has a significantly long half-life of $\sim 30$ years and is observed in a wide area of the northwestern Pacific Ocean. All five groups are now considering both direct discharge and atmospheric deposition in their calculations, but we discuss here only the results without atmospheric deposition.

\section{SOURCE ESTIMATION}

The temporal evolution and amount of radioactivity released to the ocean and atmosphere from the plant are key pieces of information for dispersion simulations. In general, the source conditions are not readily available for this kind of accident, leaving a large uncertainty in the simulated results. One of the main purposes of the oceanic dispersion simulations is, therefore, to estimate the source information, using inversion techniques, as accurately as possible. So far, several estimates of the amount of ${ }^{137} \mathrm{Cs}$ discharged into the ocean have been reported, which are summarized in Table 2 and Figure 1 . Note that the values come not only from peer-reviewed scientific papers but also from unreviewed articles.

TEPCO reported that the estimated total amount of ${ }^{137} \mathrm{Cs}$ discharged directly into the ocean through a crack in the concrete wall near the reactor of Unit 2 during April 1-6 was 0.94 petabecquerels $(\mathrm{PBq})$, which is equivalent to about 25 kilocuries (kCi) (TEPCO 2011a). In FigUre 1, this amount is indicated by a gray bar, assuming that the discharge occurred constantly for five days from April 1. On a few other occasions, TEPCO reported discharges of contaminated water into the ocean, but those were two to five orders of magnitude smaller in terms of radioactivity than the amount released during April 1-6.

Kawamura et al. (2011) estimated the amount of ${ }^{137} \mathrm{Cs}$ discharged into the ocean (red line in FIG. 1) using radioactivity data measured near the power plant by TEPCO (2011b) (black line in FIG. 1); they assumed that the contaminated water of the observed concentration occupied an area of $1.5 \mathrm{~km}^{2}$ in front of the plant and was $1 \mathrm{~m}$ deep. After adjustment to the values reported by TEPCO for the period of April 1-6, a value of $4 \mathrm{PBq}$ was obtained. The time series of the source information thus estimated (red line in Fig. 1) shows two peaks of release at the end of March and the beginning of April, with a magnitude of about $0.4 \mathrm{PBq}_{\text {day }}{ }^{-1}$. After April 7, the discharge diminished exponentially to about $0.001 \mathrm{PBq}^{-1 a y}{ }^{-1}$ at the end of April.

On the other hand, Tsumune et al. (2011) estimated a source function of ${ }^{137} \mathrm{Cs}$ by multiplying by a factor to adjust their model results, with a unit release of the radionuclide, to the observed values, giving a total of $3.5 \mathrm{PBq}$ of ${ }^{137} \mathrm{Cs}$ discharged directly into the ocean (FIG. 1, blue line). They provided a simple scenario for the time evolution of the radionuclide discharge, in which they assumed that the time fluctuation of the observed radioactivity is associated with dispersion processes after entering the ocean. Indeed, Tsumune et al. (2011) are successful in reproducing a detailed time evolution similar to that observed at several locations along the coast south of the plant, including ${ }^{137} \mathrm{Cs}$ maxima observed on March 30 and April 6 near the plant.

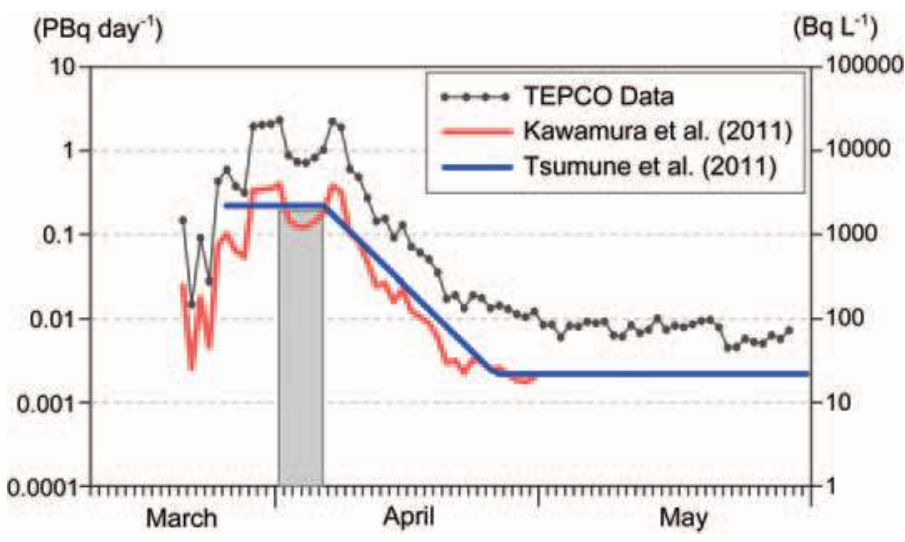

Figure 1 Time series of source information for ${ }^{137} \mathrm{Cs}$. The black Figure 1 line with solid circles is the time series of ${ }^{137} \mathrm{Cs}$ radioactivity in the open ocean near the Fukushima plant (right scale, in becquerels per liter). The values were obtained by averaging the radioactivity observed by TEPCO at the northern and southern drainage points of the plant. The red and blue lines are the time series of ${ }^{137} \mathrm{Cs}$ released into the ocean as estimated by Kawamura et al. (2011) and Tsumune et al. (2011), respectively (left scale, in petabecquerels per day). The gray bar indicates the ${ }^{137} \mathrm{Cs}$ discharge estimated by TEPCO, assuming a constant discharge between April 1 and 5 (left scale). 1 petabecquerel $(\mathrm{PBq})=10^{15} \mathrm{~Bq}$ 
Several other estimates, including those by the Sirocco, NOAA, and JCOPE groups, were basically obtained from numerical models using the TEPCO data. The values obtained by Sirocco and NOAA, about 3 to $4 \mathrm{PBq}$ of ${ }^{137} \mathrm{Cs}$ discharged directly into the ocean, are similar to those derived by Kawamura et al. (2011) and Tsumune et al. (2011). The second report from the Institut de Radioprotection et de Sûreté Nucléaire (IRSN) on the impact of radioactivity released from the plant on the marine environment (IRSN 2011a) estimated the amount of radioactivity discharged until April 11 to be $2.3 \mathrm{PBq}$, which is somewhat smaller than other estimates. Another IRSN report shows a significantly large value of $27 \mathrm{PBq}$ of ${ }^{137}$ Cs (IRSN 2011b), which seems to have been derived by simple interpolation of sparsely observed data and assuming constant radioactivity within a relatively thick surface mixed-layer in March. A relatively large estimate of 14.8 $\mathrm{PBq}$ from JCOPE is mainly due to relatively coarse horizontal resolution with a simple boundary condition, in which the simulated ${ }^{137} \mathrm{Cs}$ concentration at the sea surface in front of the plant is forced to adjust toward the observed value.

Most of the above estimates rely on radioactivity measurements by TEPCO near the nuclear plant. Errors in the TEPCO data, if any, can propagate into these estimates directly. Another factor affecting the value of estimated source information is the vertical distribution of radionuclides, especially in the oceanic surface layer. The surface mixed-layer defined by temperature or water density can be relatively thick in March due to winter cooling at the sea surface and subsequent vertical convective motion. We do not know at this stage, however, whether or not the radionuclides are also evenly distributed vertically within the surface mixed-layer. In this regard, the values in TABLE 2 should be considered to have large uncertainties.

\section{DISPERSION SIMULATIONS}

With the above-mentioned source information for simulating the dispersion of radionuclides in the ocean, time series of the three-dimensional distribution of ${ }^{137} \mathrm{Cs}$ were obtained from each model. In this section, we compare these results, focusing on the surface distribution of ${ }^{137} \mathrm{Cs}$ in the coastal and continental shelf regions during the first two months after the accident. We present 10-day averaged surface horizontal-velocity fields and ${ }^{137} \mathrm{Cs}$ distributions for two periods, from March 22 to 31 (FIG. 2) and from April 21 to 30 (FIG. 3). These periods correspond, respectively, to a time of southward dispersion along the Fukushima coast and to a time of gradual dispersion toward the margin of the continental shelf. Monitoring of the radionuclides was conducted by the Ministry of Education, Culture, Sports, Science and Technology (MEXT) and
TEPCO during March and April, 2011 (MEXT 2011; TEPCO $2011 \mathrm{~b}$ ), and comparisons of the simulated results with the observations are also made for the two periods.

\section{March 22-31}

A lack of observational data prevents us from providing a detailed description of the ${ }^{137} \mathrm{Cs}$ distribution at the end of March. The monitoring observations, however, indicate high concentrations of ${ }^{137} \mathrm{Cs}$ along the coast, near the nuclear plant (FIG. 2G). The data along a line $30 \mathrm{~km}$ offshore from the coast also show ${ }^{137} \mathrm{Cs}$ contamination, with a magnitude of about 10 to $15 \mathrm{~Bq} \mathrm{~L}^{-1}$. These observed values are significantly higher than those observed in Japanese coastal waters before the accident, a typical value of which is about $0.003 \mathrm{~Bq} \mathrm{~L}^{-1}$ (Kasamatsu and Inatomi 1998).

In general, the surface current fields in all the models show a strong eastward or northeastward flow-the Kuroshio current-along the coast of Japan south of Inubo Peninsula. The current separates from the coastal area off Inubo Peninsula. The models also show a broad southward flow, with a speed of 0.2 to $0.5 \mathrm{~m} \mathrm{~s}^{-1}$, in the region east of $141.5^{\circ}$ $\mathrm{E}$ and north of the Kuroshio current (FIG. 2A-E). All models demonstrate a weak southward flow, with a speed of $0.1 \mathrm{~m}$ $\mathrm{s}^{-1}$ or less, along the coast in front of the Fukushima plant. This southward current along the coast is responsible for the southward distribution of ${ }^{137} \mathrm{Cs}$ at the end of March. The southward flow along the coast can be traced back up to $38^{\circ} \mathrm{N}$ in all the models, while the speed of the flow varies among the models and, in the JCOPET model, is partially associated with a cyclonic circulation off the coast of Fukushima. The local flow pattern in this region is susceptible to wind forcing, which shows higher temporal variability associated with synoptic weather disturbances.

All the models fail to simulate the relatively high concentration of ${ }^{137} \mathrm{Cs}$ along a line $30 \mathrm{~km}$ offshore. Since the results shown here are the dispersions of ${ }^{137} \mathrm{Cs}$ released directly from the plant, it is reasonable to expect that this offshore contamination at the end of March was due to deposition from the atmosphere. This is consistent with the conclusion of Tsumune et al. (2011), who showed the importance of deposition from the atmosphere by checking the ${ }^{131} \mathrm{I} /{ }^{137} \mathrm{Cs}$ activity ratio.

Another important surface current pattern is eddy-like structures off the coast of Ibaraki in the region between $36.7^{\circ} \mathrm{N}$ and the Kuroshio current; in this region, the differences among the models are rather large. A clear example is an anticyclonic circulation centered at $36.4^{\circ} \mathrm{N}, 141^{\circ} \mathrm{E}$ in the CRIEPI result. A similar eddy structure can also be seen in other model results, but it is relatively weak and shifted slightly to the east in the JCOPET model, and it appears as a part of a strong dipole eddy structure in the

\section{TABLE 2}

ESTIMATED AMOUNT OF ${ }^{137} \mathrm{CS}$ DISCHARGED DIRECTLY INTO THE OCEAN

\begin{tabular}{|c|c|c|c|c|}
\hline Institution & Period & ${ }^{137} \mathrm{Cs}^{\mathrm{a}}$ & Method & Reference \\
\hline TEPCO & April 1 April 6 & 0.94 & Based on observed data & Media release \\
\hline IRSN & Up to April 11 & 2.3 & Based on observed data & IRSN (2011a) \\
\hline IRSN & March 25 July 18 & 27 & Simulated results with observed boundary conditions & IRSN (2011b) \\
\hline JAEA & March 21 April 30 & 3.58 & Based on observed data & Kawamura et al. (2011) \\
\hline CRIEPI & March 26 May 31 & 3.54 & $\begin{array}{l}\text { Unit release experiment with adjustment to observed } \\
\text { values }\end{array}$ & Tsumune et al. (2001) \\
\hline JCOPE & March 21 May 6 & 14.8 & Based on observed data & \\
\hline NOAA & March 10 June 27 & 3.6 & $\begin{array}{l}\text { Based on observed data } \\
\text { (data from Kawamura et al. 2011) }\end{array}$ & \\
\hline Sirocco & March 20 June30 & 4.2 & Inverse model based on observed data & \\
\hline
\end{tabular}


Figure 2 Ho rizontal distribution of current velocity at the sea surface $\left(0_{-1}\right.$ $\mathrm{m}$ below the sea surface for (A) CRIEPI model, (B) JAEA model, (C) JCOPET model, (D) Sirocco model, and (E) NOAA model. (F) Ensemble mean weighting the five models, averaged over 10 days from March 22 to 31. Note that the averaged period for the CRIEPI model is from March 26 to 31 , since their discharge scenario started on March 26. (G) Observed horizontal distribution of ${ }^{137} \mathrm{Cs}$ averaged over the same 10-day period. Current speeds are given by the lengths of the arrows (see scale). Radioactivity concentrations are given in becquerels per liter $\left(\mathrm{Bq} \mathrm{L}^{-1}\right)$. UDL = below detection limit; F1-NPP = Fukushima Daiichi nuclear power plant
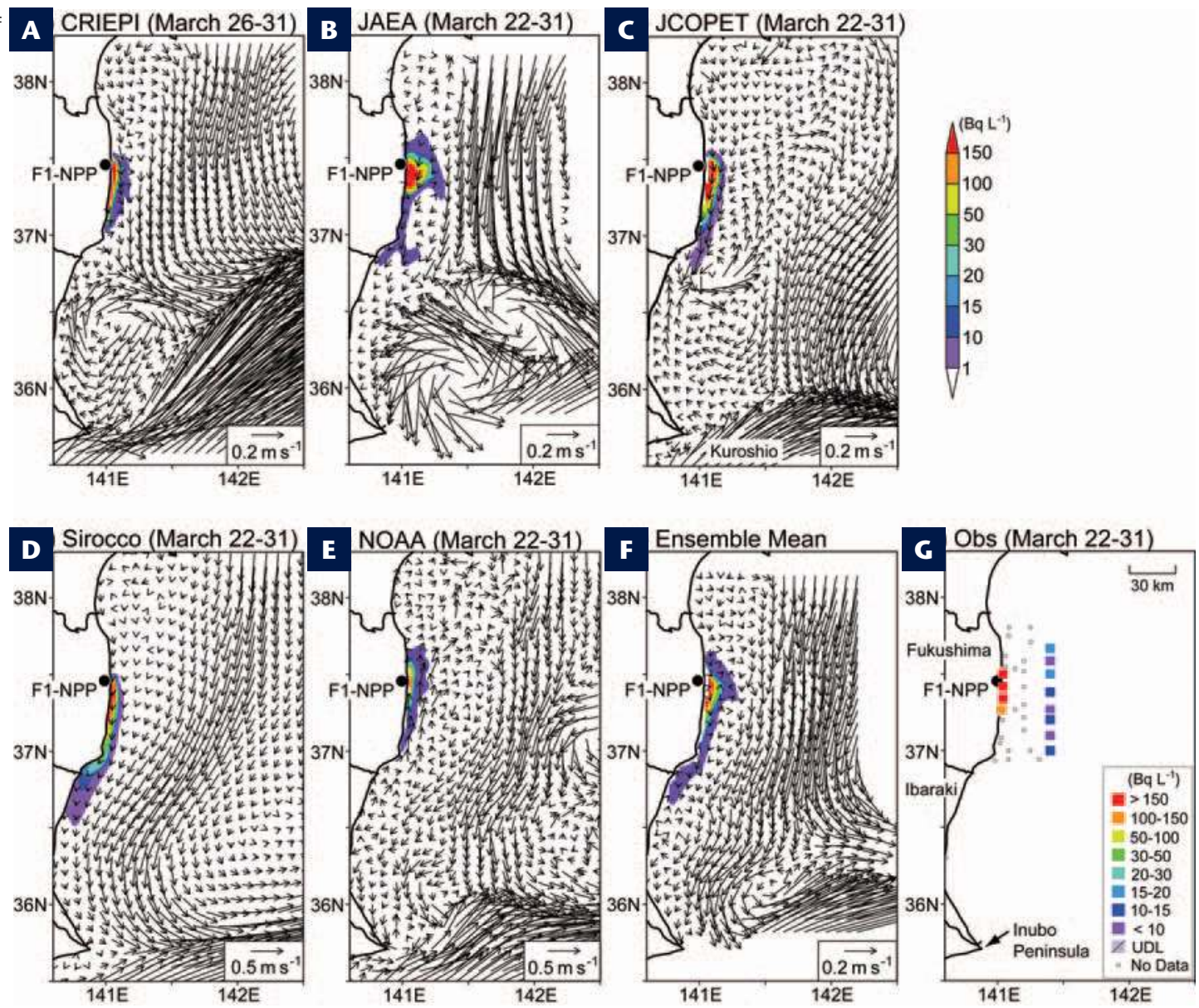

JAEA model. The Sirocco and NOAA models show relatively broad southward flow off Ibaraki. Satellite images of the sea-surface temperature distribution indicate a weak, warm-core, eddy-like feature off the coast of Ibaraki at the end of March and in early April (not shown). The ${ }^{137} \mathrm{Cs}$ concentration had not reached the region of these eddies by the end of March.

An ensemble mean of the five model results, giving equal weight in the averaging (FIG. 2F), captures most of the above-mentioned velocity and ${ }^{137} \mathrm{Cs}$ distributions. It is rather difficult, however, to show that the ensemble mean field is better at representing the observed distribution, since the observational data are so sparse and limited to a region close to the plant.

\section{April 21-30}

The high ${ }^{137} \mathrm{Cs}$ concentration had spread offshore by the end of April, while the radioactivity along the line $30 \mathrm{~km}$ offshore diminished slightly to a value of around $10 \mathrm{~Bq} \mathrm{~L}^{-1}$ or less, except for two locations, where values of more than $20 \mathrm{~Bq} \mathrm{~L}^{-1}$ were detected (FIG. 3G). New monitoring stations were installed in the region off Ibaraki, but the observed values were all under the detection level of about $10 \mathrm{~Bq} \mathrm{~L}^{-1}$ for this time period.

All the models show southward or southeastward dispersion of the ${ }^{137} \mathrm{Cs}$ in the latter part of April (FIG. 3A-E). The offshore dispersion seems to be associated with a nearshore, northeastward surface flow broadly distributed near the power plant in all models. The southward or southeastward movements of ${ }^{137} \mathrm{Cs}$ in the offshore region south of $37^{\circ} \mathrm{N}$, however, show large differences among the models. While the anticyclonic circulation brings the ${ }^{137} \mathrm{Cs}$ distribution southeastward in the CRIEPI and JCOPET models, the JAEA, Sirocco, and NOAA results show southward dispersion along the coast associated with a weak southward flow near the coast. The NOAA results indicate strong eddy features beyond the coastal region, but the radionuclide distribution was not affected by the eddies at the end of April. The differences among the models suggest that the surface circulations in the region between $37^{\circ} \mathrm{N}$ and the Kuroshio current are susceptible to mesoscale eddy activity and to variability of the Kuroshio, and the modeled Kuroshio current is in turn strongly affected by dataassimilation processes in the larger domain models. In addition, the radionuclide distribution is affected by velocity fields not only during April 21-30 but also before that period. Again, the ensemble mean fields capture reasonably well the main features of the ${ }^{137} \mathrm{Cs}$ distribution and the velocity characteristics off Fukushima and Ibaraki (FIG. 3F).

In addition to the mesoscale eddy activity, the magnitude of horizontal and vertical mixing processes in the ocean may strongly influence the ${ }^{137} \mathrm{Cs}$ distribution. For example, the CRIEPI and NOAA results show relatively weak values of less than $10 \mathrm{~Bq} \mathrm{~L}^{-1}$ in most of the region affected by radionuclide contamination as compared with other model results. One possible reason for this discrepancy could be differences in the magnitude of the vertical diffusivity; in general, the larger the vertical diffusivity, the weaker the surface concentration of the ${ }^{137}$ Cs. However, it is not straightforward to deduce this effect in a simple comparison among the models in Figures 2 AND 3, since each model uses different schemes for advection and diffusion as well as different diffusion coefficients. 
Figure 3 Same infor-

Figure 2, but for the period April 21-30. Note that the average period for the JAEA and NOAA models ends on April 29 and 26, respectively. For other explanations, see the caption of Figure 2.
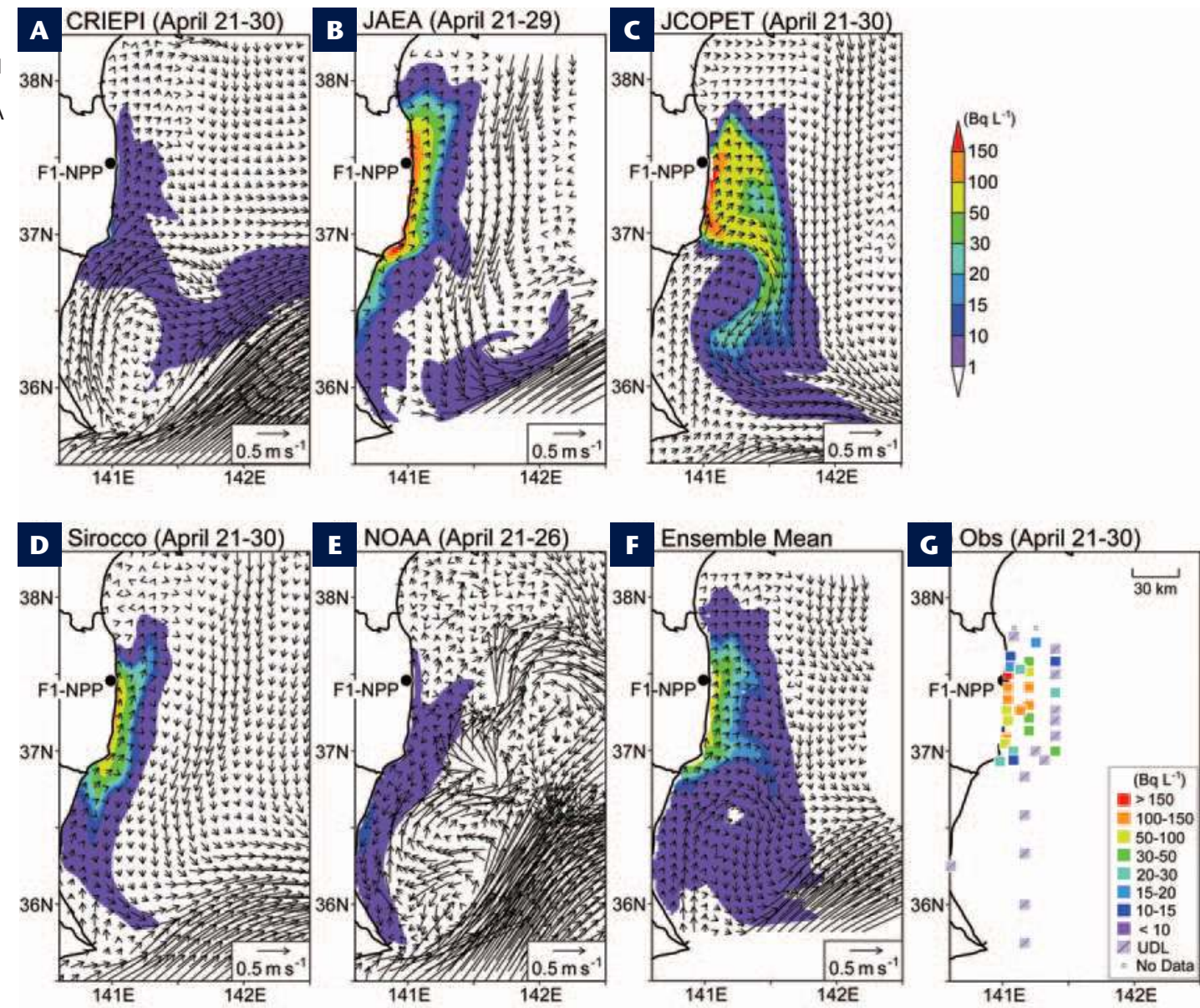

Another possible cause for the discrepancy is the degree of horizontal movement of the radionuclides within the 10-day-average window. When the radionuclides move around in a large area, the averaged concentration becomes smaller as compared with a case where radionuclides stay in the same location. This aspect strongly depends on the variability in the current system and should be evaluated in the future in order to clarify the detailed dispersion processes in this region.

At the end of April 2011, the relatively strong southward flow in the offshore region had strengthened as compared with the end of March. A major part of the ${ }^{137} \mathrm{Cs}$ distribution, however, was confined within the region between the coast and the offshore southward flow. The ${ }^{137} \mathrm{Cs}$ dispersed to the south or southeast was eventually captured in early May by the northern flank of the Kuroshio current and spread rather quickly to the east into the Pacific Ocean. This eastward movement of ${ }^{137} \mathrm{Cs}$ can be seen in all the model outputs, and one example for the JCOPET model is shown in Figure 4.

\section{FUTURE ISSUES}

Comparison of the surface horizontal distributions of ${ }^{137} \mathrm{Cs}$ among the dispersion models for the Fukushima accident demonstrates general agreement of the flow fields and associated ${ }^{137} \mathrm{Cs}$ distributions at the end of March and April 2011. However, there are noticeable differences among the models as well, in particular for the region between $37^{\circ} \mathrm{N}$ and the Kuroshio current, where cyclonic or anticyclonic eddy-like circulations can be seen in some models. Accurate representation of such mesoscale structures and associated radionuclide dispersion near the coast is an important challenge for simulations on the regional scale.

The degree of vertical mixing in a model, as well as the vertical distribution of the source term, may also affect the surface distribution of the radionuclides. During March and April, several low-pressure systems passed through the Fukushima region, and these could have produced relatively large vertical mixing in this region. We need to

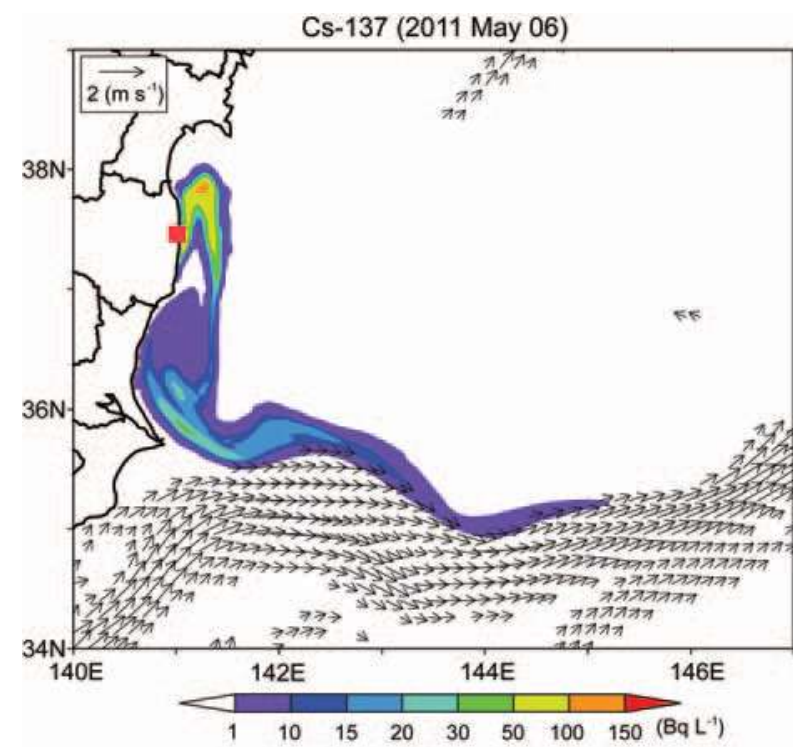

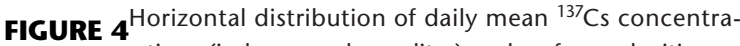
tions (in becquerels per liter) and surface velocities on

May 6 simulated by the JCOPET model. Surface velocity vectors (arrows) are drawn only in regions where the magnitude of the surface current exceeds $0.5 \mathrm{~m} \mathrm{~s}^{-1}$ to highlight the location of the simulated Kuroshio current. 
complete systematic sensitivity analyses and more detailed model intercomparisons in order to resolve these issues.

In this article, we have focused only on the dispersion of the ${ }^{137} \mathrm{Cs}$ discharged directly from the Fukushima plant into the ocean. However, ${ }^{137} \mathrm{Cs}$ was also deposited as atmospheric fallout on the sea surface over a wide region. Investigations of the relative importance of these two sources and the distribution of total ${ }^{137} \mathrm{Cs}$ concentration in the ocean are now being undertaken by several groups. Kawamura et al. (2011), for example, have discussed the noticeable impact of atmospheric deposition of ${ }^{131}$ I over a large area of the northwestern Pacific. NOAA's simulations in a larger area of the northwestern Pacific, including a component of atmospheric deposition of ${ }^{137} \mathrm{Cs}$, also agree with this assessment. Tsumune et al. (2011) pointed out that the contribution by direct release to the observed ${ }^{137} \mathrm{Cs}$ concentrations near the Fukushima coast in the latter part of March and in April was larger than that resulting from atmospheric deposition. Further intercomparison studies on the impact of atmospheric deposition are necessary. Other possible contributors to the contaminated water, such as rivers and groundwater, should also be taken into account.

Another important point for accurate dispersion calculations is to consider ocean processes that scavenge radionuclides, including adsorption onto particulates and absorption due to biological processes. At present, only a few groups are trying to integrate these processes into their models. The incorporation of better-performing models of scavenging mechanisms into dispersion simulations in the ocean will be essential.

\section{CONCLUDING REMARKS}

We have reviewed the present status of oceanic dispersion simulations of radionuclides discharged from the Fukushima nuclear plant. There are large differences in the models and model settings among the research groups, leading to different results for ocean currents near Fukushima and, hence, for the distributions of radionuclides such as ${ }^{137} \mathrm{Cs}$. At the moment, we cannot say that one model is better than another. Rather, we need to be able to explain the discrepancies and reduce the overall uncertainty of the dispersion simulations. The International Atomic Energy Agency is now coordinating a more detailed model intercomparison in order to facilitate this research. Insights into oceanic dispersion gained through such international efforts will facilitate implementation of more predictive models.

According to the TEPCO data obtained near the Fukushima plant, ${ }^{137} \mathrm{Cs}$ radioactivity at the end of April 2012 was of the order of $1 \mathrm{~Bq} \mathrm{~L}^{-1}$. Results from recent observations and numerical models indicate that the distribution of ${ }^{137} \mathrm{Cs}$ has expanded and shifted to the east into a large portion of the North Pacific Ocean, while the radioactivity in most of the area is of the order of, or below, $0.01 \mathrm{~Bq} \mathrm{~L}^{-1}$. In order to describe what happened and is happening in terms of the dispersion of radionuclides from the Fukushima plant, research-based, accurate observations and analyses in a wide area of the North Pacific Ocean for more than a few decades are needed; as well, detailed comparisons and a synthesis of the simulated results and observations are strongly required.

\section{ACKNOWLEDGMENTS}

YM and YM thank Drs. Sergey M. Varlamov, Ruochao Zhang, Toshimasa Doi, and Toru Miyama for their support of JCOPE simulations. LL is deeply grateful for support from Dr. John Cortinas, Dr. Frank Bub, Mr. Robert Daniels, Mr. Richard Patchen, and Ms. Hong Lin for NOAA dispersion simulations.

\section{REFERENCES}

Barron CN, Kara AB, Hurlburt HE, Rowley C, Smedstad LF (2004) Sea surface height predictions from the Global Navy Coastal Ocean Model (NCOM) during 1998-2001. Journal of Atmospheric and Oceanic Technology 21: $1876-1894$

Hashimoto A, Hirakuchi H, Toyoda Y, Nakaya K (2010) Prediction of regional climate change over Japan due to global warming (Part 1) - Evaluation of Numerical Weather Forecasting and Analysis System (NuWFAS) applied to a long-term climate simulation. CRIEPI report N10044, 22 pp (in Japanese)

IRSN (2011a) Impact on marine environment of radioactive releases resulting from the Fukushima-Daiichi nuclear accident. Institut de Radioprotection et de Sûreté Nucléaire, 9 pp, www.irsn.fr/ EN/news/Pages/201103_seism-in-japan. aspx

IRSN (2011b) Update: Impact on the marine environment of radioactive releases following the nuclear accident at Fukushima Daiichi. Institut de Radioprotection et de Sûreté Nucléaire, May 13, 2011, 16 pp, www.irsn.fr/EN/ news/Pages/201103_seism-in-japan.aspx

Ishikawa Y, Awaji T, Toyoda T, In T, Nishina K, Nakayama T, Shima S, Masuda S (2009) High-resolution synthetic monitoring by a 4 -dimensional variational data assimilation system in the northwestern North
Pacific. Journal of Marine Systems 78: 237-248

Kanamitsu M, Ebisuzaki W, Woollen J, Yang S-K, Hnilo JJ, Fiorino M, Potter GL (2002) NCEP-DEO AMIP-II Reanalysis (R-2). Bulletin of the American Meteorological Society 83: 1631-1643

Kasamatsu F, Inatomi Y (1998) The effective environmental half-life of ${ }^{90} \mathrm{Sr}$ and ${ }^{137} \mathrm{Cs}$ in coastal seawaters of Japan. Journal of Geophysical Research 103: 1209-1217

Kawamura H, Kobayashi T, Furuno A, In T, Ishikawa Y, Nakayama T, Shima S, Awaji T (2011) Preliminary numerical experiments on oceanic dispersion of ${ }^{131}$ I and ${ }^{137} \mathrm{Cs}$ discharged into the ocean because of the Fukushima Daiichi Nuclear Power Plant disaster. Journal of Nuclear Science and Technology 48: $1349-1356$

Kobayashi T, Otosaka S, Togawa O, Hayashi K (2007) Development of a non-conservative radionuclides dispersion model in the ocean and its application to surface cesium-137 dispersion in the Irish Sea. Journal of Nuclear Science and Technology 44: 238-247

MEXT (2011) Monitoring information of environmental radioactivity level. http://radioactivity.mext.go.jp/en/ monitoring_around_FukushimaNPP_ sea/

Miyazawa Y, Zhang R, Guo X, Tamura H, Ambe D, Lee J-S, Okuno A, Yoshinari H, Setou T, Komatsu K (2009) Water mass variability in the western North Pacific detected in a 15 -year eddy resolving ocean reanalysis. Journal of Oceanography 65: 737-756

Shchepetkin AF, McWilliams JC (2005) The regional ocean modeling system (ROMS): a split-explicit, free-surface, topography-following-coordinate oceanic model. Ocean Modelling 9: 347-404

TEPCO (2011a) Fukushima Daiichi Nuclear Power Station Unit 2: Countermeasures to stop the outflow of contaminated water and the water amount flowed out into the sea. Tokyo Electric Power Company, press release April 21, 2011, www.tepco.co.jp/en/ press/corp-com/release/11042103-e.html

TEPCO (2011b) Detection of radioactive materials from seawater near Fukushima Daiichi Nuclear Power Station, www. tepco.co.jp/en/nu/fukushima-np/f1/ index2-e.html

Toulouse University (2011) http://sirocco. omp.obs-mip.fr/outils/Symphonie/ Produits/Japan/SymphoniePreviJapan. htm

Tsumune D, Tsubono T, Aoyama M, Hirose K (2011) Distribution of oceanic ${ }^{137} \mathrm{Cs}$ from the Fukushima Dai-ichi Nuclear Power Plant simulated numerically by a regional ocean model. Journal of Environmental Radioactivity (in press) 